\title{
Potential contribution of branchwood quantity, left after logging operations, towards reducing depletion rate and preserving Ghana's forest ecosystem
}

\author{
PETER KESSELS DADZIE
}

Interior Architecture and Furniture Production Department, Kumasi Polytechnic, Kumasi, Ghana, West Africa

Email address:

pkkdadzie@yahoo.com, peter.kdadzie@kpoly.edu.gh

\section{To cite this article:}

PETER KESSELS DADZIE. Potential Contribution of Branchwood Quantity, Left after Logging Operations, Towards Reducing Depletion Rate and Preserving Ghana's Forest Ecosystem. American Journal of Agriculture and Forestry.

Vol. 1, No. 2, 2013, pp. 32-39. doi: 10.11648/j.ajaf.20130102.12

\begin{abstract}
The alarming depletion rate of Ghana's forests has become one major challenge facing the wood related industries, foresters and environmentalists. This is because, depletion of forest and wood lands do not only affect industrial and economic growth negatively, but also disturbs the whole forest ecosystem. The depletion rate has largely been attributed to the practice of extracting only the stemwoods of trees felled, to meet demand for wood and leading to continuous felling of trees. Branchwood is viewed as one possible supplement to stemwoods, and when extracted for use, can help reduce the extinction rate and subsequently help to preserve the forests and the environment. This study was conducted to ascertain the quantity of merchantable branchwood left in Ghana's forests, after logging operations, to suggest a possible commercial conversion to supplement stemwood. Data was gathered from four natural forest reserves in three ecological zones. Volumes of merchantable branchwoods on 106 felled trees were computed using Smalian's equation. These trees were sampled based on accessibility to their branches. Two diameters at each end (ranged from $18 \mathrm{~cm}$ and $90 \mathrm{~cm}$ ) and one length of each branchwood were measured for volumes computations. Branchwwood volumes of individual trees and those of same species were tallied and their means determined. Results indicated that, merchantable branchwood volumes ranged from $2.302 \%$ (Pterygota macrocarpa) to $63.841 \%$ (Khaya spp.) of their extracted stemwood volumes. However, the overall average merchantable branchwood volume was found to be $28.602 \%$ of the total extracted stemwood volume from the 106 trees. This percentage translates into preserving or conserving about 6 hectares of forest land area, should branchwood be extracted for use. It was concluded that, the average branchwood volume is substantial enough for commercial lumber production to supplement stemwood and help reduce the high depletion rate.
\end{abstract}

Keywords: Ghana's Forests Ecosystem, Depletion Rate, Stemwood, Merchantable Branchwood, Smalian's Equation

\section{Introduction}

Forests and woodlands play very important environmental and economic roles in many countries, including Ghana. Environmentally, the forest cover protects the soil from erosion, protect rivers and streams from drought to ensure quality water availability for consumption, and help to provide continuous and sustainable clean air for living organisms like man [1-3]. As a result, both the living and nonliving components of the forest ecosystems are interconnected, interrelated and interdependent, and all contributes to the sustenance of human life on earth. However living and non living lives are much dependent on trees, and for that matter, forests.
According to [4] some of the importance of forests or trees include; the prevention of soil erosion to make arable soil or land available for food and cash crop plantations to sustain human life, the protection of water sheds and rivers to ensure continuous availability of water for both animal and human activities. The author contends that trees reduce wind movement near and above the ground in their vicinity, which in turn provide protection and comfort to man, properties and agricultural crops. All such importance of forests or plants in relation to their direct and indirect sustenance of human life cannot be disputed, and as such, frantic efforts have to be made to ensure the existence and preservation of forests or plants worldwide. In the wake of Ghana's current state of continuous increase in efforts at extending crude oil exploration and production activities, 
the forest cover, especially the trees, have got to play another very essential environmental role of carbon sequestration $[5,2]$. This is essential for the prevention of eminent carbon dioxide related infections and diseases and to ensure food safety in the country.

Economically, forests provide timber and other products that serve as one major foreign exchange earner for Ghana's economy and raw material base for the country's timber related industries, and also provide jobs for the citizenry of the country. Export of timber products is ranked third in Ghana's export products mix and provided $7 \%$ by value of all exports in 2011 [5].

Meanwhile these economic and environmental roles are best provided by matured trees. It has been found and reported that not all trees in the forests can either be converted to timber for any economic gain or be able to protect crops and river bodies or to sequester carbon to any appreciable level toward the protection of the forest ecosystem and the environment in general. According to [2], old forests, and for that matter matured trees, sequester more carbon than they emit and thus providing a favorable net carbon sink compared to young or 'adolescent' trees that emits more carbon than they are able to sequester. Economically too, both young and 'adolescent' trees have less diameter or less percentage of heartwood and would eventually provide very little or no timber of any good mechanical strength to attract any appreciable economic value [6].

Unfortunately, the adult or matured forest trees that can perform these important environmental and economic roles continue to be depleted at an alarming rate and thereby threatening those roles played by the forests. The annual decline of the forest estate of Ghana has, between 1990 and 2005 experienced a rate of $2 \%$ per annum. This percentage arises from losses of 135, 000 hectares from 1990 to 2000 and 115,000 hectares from 2000 to 2005 [7]. This depletion trend has been attributed to; demand for wood, inefficient logging and processing practices, and misuse of wood secondary resources like branches [8].

The consequential effects of this dwindling syndrome are economically and environmentally negative on the forest ecosystem, the citizenry, and the country's economy and environment at large. This is because the situation, among other things, has led to the turning of some forest and wood lands, which protect the soil and river bodies, into deserts. The scarcity of raw materials (wood) has also compelled some wood processing and furniture production companies to either fold-up or not operating at full capacity, which has subsequently led to loss of jobs and income to individuals, firms and the nation. Against the background of this disturbing and threatening situation of dwindling timber resources for the wood related industries and their consequential negative economic and environmental effects, searching for alternatives has become one top priority problem to stakeholders in the wood industries [9]. This is because, it is expected that, the supplements will at least; provide raw materials to keep remaining wood related firms in business for economic growth, slow down the high depletion rate and also help to preserve the forests ecosystems and the environment.

Though, one way of tackling the depletion rate has been the pursuance of plantation forestry. However, it is a longterm solution since even a fast-growing plantation trees take between 6 to 30 years to mature [10]. Hence, in addition to plantation, there is the need for some immediate and short-term alternative sources of materials. Some of such materials are the logging residues including branches, which are readily available and have the potential for high value application to supplement stemwood [11] and ensuring whole tree usage. These logging residues have been reported to be relatively high in Ghana. According to [12], there is an estimate of about $25 \%$ of merchantable wood in the form of branches and stems that are left as residues during logging operations in Ghana's forests. Again, [1] also reports that, for every tree felled, nearly $50 \%$ of its volume is left in the forest as residues in the form of branchwood, crownwood and stumps. Meanwhile utilizing these volumes of residues would mean compliance with the whole-tree concept, reducing waste in logging and timber processing, and also serve as one way of meeting the supply demand of wood related industry [13].

Industrial utilization of wood residues, like branches, has therefore become one subject of interest to researchers and industry. In the light of this, their strength properties for a possible commercial utilization, in Ghana, has been investigated by some researchers including, [1, 12-16]. All these studies compared some physical and mechanical properties of stemwood with branchwood. But information on branchwood quantity is very limited to $[12,14]$ who considered quantifying the volume of branchwood but their studies centered on only 3 compartments and their data was collected just after felling. But volume or quantity is one vital variable that influences total return on any investment [10] and therefore an important criterion for acceptance of a possible commercial conversion of branchwood to supplement stemwood.

Meanwhile logging does not end at felling but continues through skidding to loading of logs onto trucks [17]. Observations also indicate that, during these processes of extracting the main bole, some branches can be destroyed. Thus quantifying branchwood volume after complete logging process will present a more reliable data of the volume of branch logs that are left in the forests after logging operations. This is so because, that is the expected real situation to occur if anyone wants to extract branch logs for processing since concessioners would normally extract the main bole logs first before any extraction of residues could be allowed. Moreover, tree behaviour and structure, including crown or branchwood quantity vary from one ecological zone to the other due to different climatic conditions at the sites where they are located [6]. Thus covering more compartments will help to make a better assessment of branchwood quantities per species. It is in the light of these that this research was conducted to 
ascertain merchantable branchwood volume left in Ghanaian tropical forests after logging operations by covering different ecological zones in different regions. This research sought to determine;

- The quantity (volume) of merchantable branchwood left in Ghanaian tropical forests after logging that has the potential to be used for lumber production to supplement stemwood.

- The relationship (ratio or percentage) of extracted stem log (main bole) volume to branchwood or branch log volume to predict the forest area that could be preserved at a time, if branchwood is extracted and processed for use.

\section{Methodology}

\subsection{Research Design}

The research was to quantify branchwood volume left after logging operations and to establish percentage(s) of the relationships existing between branchwood and extracted main bole/stem volume. The study was undertaken to cover a total of 8 compartments in 4 reserves and within 4 ecological zones $(50 \%$ of the 8 forest ecological zones in Ghana-[3]). Only 3 compartments were used by [14] in assessing logging efficiency and development of allometric models for predicting stumpage volume of some commercial tree species in Ghana.

The forest reserves used in this research included: Asukawkaw reserve located at Nkawkaw in the Eastern Region which is a moist semi-deciduous(South-East type) forest and lying within the boundaries of longitude $1^{0} 0^{0}$ and $0^{0} 0^{0} \mathrm{~W}$, and latitude $6^{0} 0^{0}$ and $7^{0} 0^{0} \mathrm{~N}$; Abonyere and Bosampopo reserves which are all located at Akordie in the Brong Ahafo Region- Dry Semi-deciduous Inner Zone forests and lying within the boundaries of longitude $2^{0} 0^{0}$ and $3^{\circ} 0^{0} \mathrm{~W}$, and latitude $7^{0} 0^{\circ}$ and $8^{0} 0^{\circ} \mathrm{N}$; and finally, Suii reserve located at Sefwi Wiawso in the Western Region - a Moist Evergreen Zone forest and lying within the boundaries of longitude $2^{0} 0^{0}$ and $3^{0} 0^{0} \mathrm{~W}$ and latitude $6^{0} 0^{0}$ and $7^{0} 0^{0} \mathrm{~N}$ [5]. All these reserves/compartments are concessions of Lumber and Logs Company Ltd. (LLL) - a timber processing firm in Kumasi in the Ashanti Region of Ghana. These 4 sampled forest reserves are within 3 administrative regions of Ghana, namely Eastern, Western and Brong-Ahafo Regions (all together is $60 \%$ of the 5 main regions that have forest reserves and which posses about $71.62 \%$ of total forest estate of Ghana-[3]).

This research measured two perpendicular diameters at both ends and one length of all accessible merchantable branch logs, that can be used for lumber production, and subsequently applied Smalian' formula to compute volumes using excel spreadsheet software.

\subsection{Sampling Procedure}

Sampling trees to collect data on their merchantable branches were done randomly based on accessibility since data collection commenced after the trees have been felled and hauled. This was accomplished by walking along haulage paths and other routes in the forests to sight stumps or branches of trees already felled and the main boles already skidded/hauled away. Measurements of diameters and lengths were done on all accessible branches on each tree found. For branches that were found covered with little foliage, cutlasses were used to create accessibility in order to be able to collect data on their diameters and lengths. However, there were others that the foliage on them was so much to allow accessibility.

In all, a total of One Hundred and Six (106) trees comprising thirteen (13) species were covered during the sampling. It has been indicated by [18] that, a sample of forty (40) trees is normally satisfactory for estimating volumes of tree stems and their branches and even for testing the adequacy of equations. Although [14] used 135 timber trees to predict stumpage volume of commercial species in Ghana, [19] used three (3) trees to calculate wood volume and stem taper of both stem and branch woods of a species (Eucalyptus regnans).

The various species covered in the sample included: Dahoma (Piptadeniastrum africanum), Kyenkyen (Antiarisn toxicaria), Wawa (Triplochiton scleroxylon), Essa (Celtis mildbraedii), Edinam (Entandophragma angolense), Mahogany (Khaya spp.), Sapele (Entandophragma cylindricum), Ofram (Terminalia superba), Yaya (Amphimas pterocarpoides), Onyina (Ceiba pentandra), Danta (Nesogordonia papaverifera), Denya (Cylicodiscus gabunensis) and Koto/Kyere (Pterygota macrocarpa). For each of these species, a total of two (2) to twenty-six (26) trees were captured. Every available, identified and accessible merchantable branch logs were measured. In similar studies, [19] used 3 trees for calculating stem and branchwood volume of a species whereas [14] also used, for each species, from one (1) to fifty-seven (57) trees.

\subsection{Data Collection}

Merchantable branch logs, in terms of suitability for lumber production, were considered to be branches without sweeps or crooks and also excluding the basal portions of branch forks (which are basically knots). As a result, measurements on branch logs were done in segments. Although [18] measured branch segments from fork to fork, but this includes the base of the forks which are knots and are not considered in this study as being part of merchantable log for lumber production. This is because knots reduce both the tensile and compressive strength of lumber and, depending on its size, can pose sawing difficulties like blunting of saws etc. [6]. For each merchantable branch $\log$ segment, 2 diameters perpendicular to each other were measured at both ends, whereas 1 length was measured from one end to the other on the forest fields. Measured diameters ranged from $18 \mathrm{~cm}$ to $90 \mathrm{~cm}$ whereas lengths ranged from 0.4 meter to 11.10 meters. Diameters of $18 \mathrm{~cm}$ were the minimum used 
because, according to [20] branch logs of diameters greater or equal to $50 \mathrm{~mm}$ are considered to be normal branch logs.

The mean values of each end's diameters and the length were computed and factored into Smalian's formula; $\mathrm{V}=$ $\left(D^{2}{ }_{S}+D^{2}{ }_{B}\right) \times L \times C$, to estimate the volume of each branch $\log$ segment accessed. Where: $\mathrm{V}=$ Volume of the $\log$ in cubic meters $\left(\mathrm{m}^{3}\right)$, Ds $=$ small end diameter in centimeters $(\mathrm{cm}), \mathrm{D}_{\mathrm{B}}=$ Large/big end diameter in centimeters $(\mathrm{cm}), \mathrm{C}$ (constant) $=0.00003926991$ and $\mathrm{L}=$ Log length in meters (m) [21].

Because the trees were already felled and stem logs hauled before measurements were done, Diameters at Breast Height $(\mathrm{DBH})$ were not obtainable for inclusion in the data. However, each tree's number was taken from the stumps and used to trace the actual extracted volumes, from the company's loading yard records, and also tallied for comparison.

All branchwood volumes of all segments obtained from each tree were tallied to determine the total branch volume $\left(\mathrm{V}_{\mathrm{b}}\right)$ for the tree. Afterwards, trees were grouped into species and their mean branchwood or branch log volumes determined by dividing the total volume of all trees in the group by the number of trees in that species' group. Even though actual measurements on all accessible branches on each tree were measured, in some cases, there were identified branches which were not accessible for measurements of two diameters at each end or full length owing to the volume of foliage that covered them and their locations (in streams, far above reachable heights, in valleys etc). For such branches, measurements were estimated as was done by [19].

The extracted main bole/stem log volumes $\left(\mathrm{V}_{\mathrm{el}}\right)$ for all trees were obtained from the company's log loading-yard records by using the trees' numbers on their stumps. The trees were then grouped into species and their mean extracted log volumes determined by dividing the sum of the volumes of all trees in the group by the number of trees that species' group.

\subsection{Data Analysis}

The data obtained on merchantable branch wood/ log volumes $\left(\mathrm{V}_{\mathrm{b}}\right)$ and extracted main stem/log volumes $\left(\mathrm{V}_{\mathrm{el}}\right)$ of the various species were quantitatively analyzed using excel spreadsheet software. During this process, tables and graphs were used to show any existing relationship between the two volumes pictorially. Ratios (in percentage) of relations between them $\left\{\left(\mathrm{V}_{\mathrm{el}} / \mathrm{V}_{\mathrm{b}}\right) * 100\right\}$ were also determined for a possible prediction of expected merchantable branch log volume from the extracted main bole/stem volume.

\section{Results and Discussions}

\subsection{Branchwood/Branch Log Volumes $\left(V_{b}\right)$}

Results from the study on branch log volumes per species are as presented in Table1.

Table1: Species'Branchwood/ Branch log Volumes.

\begin{tabular}{|c|c|c|c|c|}
\hline Species & Count & $\begin{array}{l}\text { Mean vol. } \\
V_{b}\left(m^{3}\right) \& \\
\text { Stand. Dev. }\end{array}$ & $\begin{array}{l}\text { Min. Vol. } \\
\left(\mathbf{m}^{3}\right)\end{array}$ & $\begin{array}{c}\text { Max. Vol. } \\
\left(\mathrm{m}^{3}\right)\end{array}$ \\
\hline Dahoma (Piptadeniastrum africanum) & 22 & $6.003(3.511)$ & 0.792 & 12.673 \\
\hline Kyenkyen (Antiaris toxicaria) & 7 & $4.282(2.688)$ & 1.043 & 9.096 \\
\hline Wawa (Triplochiton scleroxylon) & 26 & $2.815(2.225)$ & 0.518 & 9.774 \\
\hline Essa (Celtis mildbraedii) & 10 & $2.098(2.654)$ & 0.251 & 9.198 \\
\hline Edinam (Entandrophragma angolense) & 3 & $6.524(2.955)$ & 3.142 & 8.602 \\
\hline Mahogany (Khaya spp.) & 4 & $7.781(3.544)$ & 4.604 & 12.544 \\
\hline Sapele (Entandrophragma cylindricum) & 8 & $3.623(1.806)$ & 2.310 & 7.820 \\
\hline Ofram (Terminalia superba) & 12 & $1.884(1.430)$ & 0.256 & 4.907 \\
\hline Yaya (Amphimas pterocarpoides) & 2 & $7.521(6.184)$ & 3.148 & 11.893 \\
\hline Onyina (Ceiba pentandra) & 5 & $2.643(1.185)$ & 0.730 & 3.972 \\
\hline Danta (Nesogordonia papaverifera) & 2 & $3.494(0.533)$ & 3.117 & 3.871 \\
\hline Denya (Cylicodiscus gabunensis) & 2 & $6.615(3.311)$ & 4.274 & 8.956 \\
\hline \multirow[t]{2}{*}{ Koto/Kyere (Pterygota macrocarpa) } & 3 & $0.603(0.322)$ & & \\
\hline & & & 0.259 & 0.898 \\
\hline TOTAL & 106 & $55.886(2.347)$ & & \\
\hline
\end{tabular}

Note: numbers in brackets are standard deviations.

From Table 1, out of the 106 trees whose branches were accessible for data collection and subsequent volumes determination, Wawa (Triplochiton scleroxylon) species happened to be more in the sample population with a count of 26 trees. Following Wawa was Dahoma (Piptadeniastrum africanum) with a count of 22 trees whereas Yaya (Amphimas pterocarpoides), Danta (Nesogordonia papaverifera) and Denya (Cylicodiscus gabunensis) had the least appearance in the sample mix with counts of 2 trees each.

These findings of number of trees of the various species in the sample mix as indicated in Table 1 seem to confirm the findings of [22] that Wawa and Dahoma are among the abundant species in Ghana's forests. However, this study' findings in respect of Danta (Nesogordonia papaverifera) and Denya (Cylicodiscus gabunensis) turn to disagree with the Author that those species are either plentiful or abundant in Ghana's forests. However, this disparity in 
findings might be due to the reason that, this study was based on accessibility of the branch logs after the main stem logs had been skidded from its position after felling. It is therefore possible that the branches of most of these tree species were destroyed during skidding or hauling and for that matter, data were not collected on them to allow for their counting. This situation of low number of these species in the sample population mix may also be due to high level of difficulty in sighting and or accessing their branches due to the volume of foliage that covered them. This situation was observed with Denya, in at least two of the forest reserves visited.

In terms of the quantity or volume of branchwood, as indicated in Table 1, the mean branchwood volumes obtained in this study ranged from a minimum of $0.603 \mathrm{~m}^{3}$ for Koto/Kyere (Pterygota macrocarpa) to a maximum of $7.781 \mathrm{~m}^{3}$ for Mahogany (Khaya spp. -anthotheca \& ivorensis). However all the 106 trees from 13 species gave a cumulative mean branch log volume of $55.886 \mathrm{~m}^{3}$.

the high value of Mahogany (Khaya spp.) $-7.781 \mathrm{~m}^{3}$ compared to the low value for Koto/Kyere $-0.603 \mathrm{~m}^{3}$, even though their number of appearance in the sample population mix were close ( 4 and 3 respectively), indicates that Mahogany has much merchantable branches than Koto. However, observing the findings, in respect of the branch log volumes for the species mostly used for furniture and other structural applications in Ghana \{Edinam (Entandrophragma angolense), Mahogany (Khaya spp.), Dahoma (Piptadeniastum africanum)\} which obtained relatively high volumes of $6.524 \mathrm{~m}^{3}, 7.781 \mathrm{~m}^{3}$, and $6.003 \mathrm{~m}^{3}$ respectively might have been influenced by their diameters. It has been indicated that, tree and log volume strongly depend on their diameters and heights/lengths [23]. However, [21] asserts that diameter has much influence on $\log$ yields (volumes) than the lengths. Meanwhile the total mean merchantable branch logs volume that can be processed for lumber stood at $54.886 \mathrm{~m}^{3}$, implying that, for every 106 trees felled, it is likely to obtain branch logs whose average volume will be about $54.886 \mathrm{~m}^{3}$.

\subsection{Extracted Main Bole or Stem Log Volume $\left(V_{e l}\right)$}

Results on extracted main stem log volume per species as obtained from the company's records are as presented in Table2.

Table2: Extracted Main Stem log Volumes (Vel.)

\begin{tabular}{llllc}
\hline Species & Count & $\begin{array}{l}\text { Mean vol. } \\
\mathbf{V}_{\mathrm{el}}\left(\mathbf{m}^{\mathbf{3}} \mathbf{)} \boldsymbol{8}\right. \\
\text { Stand. Dev. }\end{array}$ & $\begin{array}{c}\text { Min. Vol. } \\
\left(\mathbf{m}^{\mathbf{3}}\right)\end{array}$ & $\begin{array}{c}\text { Max. Vol. } \\
\left(\mathbf{m}^{\mathbf{3}}\right)\end{array}$ \\
\hline Dahoma (Piptadeniastum africanum) & & $15.253(8.573)$ & 0.000 & 33.556 \\
Kyenkyen (Antiaris toxicaria) & 22 & $20.415(9.336)$ & 10.455 & 38.900 \\
Wawa (Triplochiton scleroxylon) & 7 & $14.693(6.635)$ & 1.200 & 36.270 \\
Essa (Celtis mildbraedii) & 26 & $10.208(4.275)$ & 4.708 & 17.280 \\
Edinam (Entandrophragma angolense) & 10 & $19.561(6.694)$ & 12.544 & 25.876 \\
Mahogany (Khaya spp.) & 3 & $12.188(6.837)$ & 4.578 & 19.152 \\
Sapele (Entandrophragma cylindricum) & 8 & $14.253(3.274)$ & 11.284 & 20.700 \\
Ofram (Terminalia superba) & 12 & $10.059(1.691)$ & 6.820 & 12.420 \\
Yaya (Amphimas pterocarpoides) & 2 & $18.193(4.675)$ & 14.887 & 21.498 \\
Onyina (Ceiba pentandra) & 5 & $30.089(8.567)$ & 14.820 & 34.640 \\
Danta (Nesogordonia papaverifera) & 2 & $9.916(0.945)$ & 9.248 & 10.584 \\
Denya (Cylicodiscus gabunensis) & 2 & $18.088(0.458)$ & 17.764 & 18.411 \\
Koto/Kyere (Pterygota macrocarpa) & 3 & $7.082(1.035)$ & & 8.225 \\
TOTAL & & & & \\
\hline
\end{tabular}

Note: numbers in brackets are standard deviations.

From Table2, out of the 106 trees sampled and whose branches were accessible for data collection, Onyina (Ceiba pentandra) species had the highest mean stem log volume of $30.089 \mathrm{~m}^{3}$ (with minimum and maximum mean values of $14.820 \mathrm{~m}^{3}$ and $34.640 \mathrm{~m}^{3}$ respectively). Kyenkyen (Antiaris toxicaria) followed Onyina with a mean extracted main stem volume of $20.415 \mathrm{~m}^{3}$ (minimum and maximum values of $10.455 \mathrm{~m}^{3}$ and $38.900 \mathrm{~m}^{3}$ respectively) whereas Koto/Kyere (Pterygota macrocarpa) had the least mean extracted main stem volume of $7.082 \mathrm{~m}^{3}$ (minimum value $=$ $6.209 \mathrm{~m}^{3}$ and maximum value $=8.225 \mathrm{~m}^{3}$ ). However the main bole/stem volume of all the 106 trees from the 13 species produced a cumulatively mean value of $199.998 \mathrm{~m}^{3}$.

Although [23] holds the view that, tree and log volume strongly depends on their diameters and heights/lengths,
[24] attributes differences in volumes among species to differences in genetics, growth and site quality. However, because it is the genetics, growth and site conditions that possibly lead to diameter and length/height differences, some or all of these factors might be responsible for the differences in the results obtained in this study. In all, the main stem volume of all the 106 trees from the 13 species produced a cumulative mean value of $199.998 \mathrm{~m}^{3}$. This implies that, if 106 Ghanaian hardwood trees are felled, the total extracted main stem volume is about $199.998 \mathrm{~m}^{3}$. In Ghana's forest sector, this extracted log volume (also called logging recovery), according to [25] is about $50 \%$ of the total merchantable tree volume. However, [14] found this logging recovery to be about $75 \%$ and attributed this relatively high percentage to the scarcity of timber in recent 
times that has necessitated the logging firms to extract more merchantable wood to meet their timber requirements. This situation seems to be actually the case, because it was observed during data collection that some of the trees were either cut just about $30 \mathrm{~cm}$ to $50 \mathrm{~cm}$ (in the case of the 'red wood' species), or a little over $1 \mathrm{~m}$ (in the case of the other species with exception of those with large buttresses) above ground level.

\subsection{Relationship between Merchantable Branchwood/Log Volumes $\left(V_{b}\right)$ and Extracted Main Bole/Stem Log Volumes $\left(V_{e}\right)$.}

The percentage relationships existing between the mean merchantable branch log volume and their corresponding mean extracted main stem volumes are as presented in Table3. From Table3, the results revealed that, Mahogany wood had the highest percentage of $63.841 \%$ whereas Koto/Kyere, had the least percentage of $2.302 \%$. Moreover, the ratios/percentages reveal that, on the average, merchantable branch log volume is about $28.602 \%$ of the extracted log volume of a tree. Thus for any cubic meter of main stem log extracted from a group of tree species, the merchantable branches' volume is expected to be about $28.602 \%$ by volume of the mean stem log volume.

Table 3: Percentage Relationship between Merchantable Branch Log Volumes $\left(V_{b}\right)$ and Extracted Main Bole/Stem Log Volume $\left(V_{\text {el }}\right)$.

\begin{tabular}{|c|c|c|c|c|}
\hline Species & Count & $\begin{array}{l}\text { Mean Ext. Stem Log } \\
\text { Vol. } V_{\text {el }}\left(\mathrm{m}^{3}\right)\end{array}$ & $\begin{array}{l}\text { Mean Merch. } \\
\text { Branch log } \\
V_{b}\left(\mathbf{m}^{3}\right) \\
\end{array}$ & $\begin{array}{l}\text { Ratio } \\
\left(V_{b} / V_{\text {el }}\right) \text { Vol. } \\
(\%) \\
\end{array}$ \\
\hline Dahoma (Piptadeniastrum africanum) & 22 & 15.253 & 6.003 & 39.356 \\
\hline Kyenkyen (Antiaris toxicaria) & 7 & 20.415 & 4.282 & 20.975 \\
\hline Wawa (Triplochiton scleroxylon) & 26 & 14.693 & 2.815 & 19.159 \\
\hline Essa (Celtis mildbraedii) & 10 & 10.208 & 2.098 & 20.553 \\
\hline Edinam (Entandrophragma angolense) & 3 & 19.561 & 6.524 & 33.352 \\
\hline Mahogany (Khaya spp.) & 4 & 12.188 & 7.781 & 63.841 \\
\hline Sapele (Entandrophragma cylindricum) & 8 & 14.253 & 3.623 & 25.419 \\
\hline Ofram (Terminalia superba) & 12 & 10.059 & 1.884 & 18.729 \\
\hline Yaya (Amphimas pterocarpoides) & 2 & 18.193 & 7.521 & 41.340 \\
\hline Onyina (Ceiba pentandra) & 5 & 30.089 & 2.643 & 8.784 \\
\hline Danta (Nesogordonia papaverifera) & 2 & 9.916 & 3.494 & 35.236 \\
\hline Denya (Cylicodiscus gabunensis) & 2 & 18.088 & 6.615 & 36.571 \\
\hline Koto/Kyere (Pterygota macrocarpa) & 3 & 7.082 & 0.603 & 8.512 \\
\hline TOTAL & 106 & 199.998 & 55.886 & 371.827 \\
\hline Average per species & 100 & 15.384 & 4.299 & 28.602 \\
\hline Average per tree & & 1.887 & 0.527 & 27.943 \\
\hline
\end{tabular}

Note: Average per species $=$ totals in columns as a ratio of the number of species (i.e. 13 species $)$. Average per tree $=(\mathrm{Vb}$ total/Vel total $) \times 100$

These results of percentage relationships between branch log volume and stem log volume (Table 3 ) seem to give hope that branch logs' proportion to extracted logs is appreciably good especially for the high monetary valued wood species and which are frequently being used in Ghana for furniture production like; Edinam, Mahogany, Sapele, and Dahoma [26]. This is because, these species' mean branch log volumes compared to their mean extracted stem log volumes produced percentages of $33.352 \%$, $63.841 \%, 25.419 \%$ and $39.356 \%$ respectively. All these percentages are at appreciable level to warrant their extraction and processing for lumber, at least, for local furniture production and other wood related works of the inhabitants of the forest area to contribute to the reduction of the depletion rate and preservation of the forests. This will also be a good avenue for fulfilling the provisions in [27] that, the local inhabitants of the contract area should be allowed to use such residues. This is fulfillment is important because, it could mainly be due to the lack of raw materials available to the local furniture and other wood related industries that partly compels the local people to engage in chainsaw operations in the forests and indiscriminately cut down trees. These operations also add up to the depletion of the forest and thereby contributing to the threat to the conservation or preservation and safety of the forest ecosystem and the environment.

On the whole, the average of all the percentages of mean extracted main log volume to mean merchantable branchwood volume stood at $28.602 \%$ (minimum value being $8.512 \%$ and maximum being $63.841 \%$ for Koto/Kyere and Mahogany respectively). However, the mean percentage branchwood per tree was $27.943 \%$ implying that on the average, volume of branchwood on each Ghanaian hardwood tree is about $27.943 \%$ of the volume of the extracted log of that tree species. This falls within the range of the findings by [11], that branchwood volume represents 25 to $32 \%$ of the total harvested wood. The finding is also within the range of [19] who found this percentage to be $28.3 \%$ for a species.

Considering the mean volume of merchantable branch $\log \left(55.886 \mathrm{~m}^{3}\right)$ and the mean extracted stem log volume $\left(199.998 \mathrm{~m}^{3}\right)$, it implies that should the branchwood/branch logs be extracted, about 29.620 trees \{(i.e. 55.886/199.998) $\mathrm{x} 106$ \} would have been preserved out of the 106 trees felled, while obtaining the same volume as will be provided by the 106 trees. It also means that if the merchantable branch logs were extracted, additional volume of $55.893 \mathrm{~m}^{3}$ (equivalent to 29.620 times the average extracted $\log$ 
volume per tree of $1.887 \mathrm{~m}^{3}$ ) could have been added to increase supply of sawn lumber to meet demand.

According to [14], in the tropical forests, about 5 trees per hectare are felled, during logging operations. Judging from this assertion, it could then be said that, the 106 trees covers a felling area of about 21.2 hectares. It also implies that, about 5.9 hectares (29.620 trees/5trees per hectare) of forest trees could have remained unlogged to protect the forest ecosystem and environment from desertification, drought, soil erosion etc. if the mills had utilized all the merchantable branchwood in addition to the stemwood extracted. In another sense, it could also mean that, wood volume from additional 5.9 hectares would have been made available for production and for subsequent extra monetary or economic gains, if the mills had utilized all the merchantable branch logs from felled trees. In terms of industrialization, raw material availability for local inhabitants and employment creation, it could also mean that there can be branchwood volume of about $28 \%$ proportion of the volumes of extracted logs available for commercial processing by, at least, cottage firms. If these firms are established in the forest communities, there will be availability of wood raw materials for various uses, which will help to curb illegal chainsaw lumbering in the forests and also create jobs for the inhabitants.

\section{Conclusion}

In this study, the quantity or volume of branchwood in comparison with extracted main stem log volume as a yardstick of assessing the potential utilization of branchwood as supplements to stem wood to reduce depletion, and preserve the forest ecosystem and environment was determined. The quantification of branchwood volumes were based on dimensions (diameters and lengths) of merchantable branch logs from 106 trees (but 13 species) using Smalian's equation. The quantities of branchwood obtained suggest that branchwood has considerable volume to supplement stemwood. What excites most, is that the main species (Edinam, Mahogany, Sapele, and Dahoma) observed to be mostly used in the local furniture manufacturing sector in Ghana appear to have branchwood volumes equivalent to more than $1 / 4$ of their extracted main log volumes. This quantity should warrant their commercialization, at least, to provide raw materials for the inhabitants of the forest area.

The appreciable proportion of the species' branchwood is a good indicator that if they are processed, there can be some raw materials available for the work of the local wood related workers. This could demotivate them to engage in illegal chainsaw lumbering and thereby contribute to decreasing the depletion rate of the forests, in order to preserve the forest ecosystem and environment. On the whole, if branch $\operatorname{logs}$ are also extracted it can supplement the main stem logs to an appreciable level and provide additional lumber volume for additional economic gains. Subsequently, the country could save substantial quantity of trees or forest lands to reduce the depletion rate of the timber resources, slow down desertification, protect soils from erosion and also protect the general environment.

From the foregoing, it is found that branchwood volumes left in the forests of Ghana after logging operations are substantial enough to supplement stem wood. It is therefore recommended that they should be processed or commercialized, at least, at the small scale village/cottage industry levels to provide raw materials to; sustain wood related businesses, protect the forest ecosystem and generate employment and income for the citizenry and the nation at large.

The Forestry Commission of Ghana should discuss the issue with the companies that are given Timber Utilization Contracts and also partner them to allow for the extraction of branchwood for processing to lumber, at least by the forest area inhabitants. This will go a long way to prevent illegal chainsaw operations and subsequently help to reduce depletion of the forests and preserve the forest ecosystem and the general environment.

\section{Acknowledgment}

My sincerest gratitude goes to Lumber and Logs Ltd. (LLL), a Ghanaian (Kumasi) based timber firm for permitting entry into its concessions for data collection. I also thank Mr. Michael Afful, a former student of Kumasi Polytechnic (Department of Interior Architecture and Furniture Production) who sacrificed and helped me in the data collection process.

\section{References}

[1] R. Okai, Can Logging Residue be used to help meet timber demands for the downstream processing sector? In: Proceedings of the XII FAO World Forestry Congress, Quebec City, Canada, 2003. http//:www.fao.org/docrep/ARTICLE/WFC/XII/0236-B4 HTM.

[2] Oregon Forest Resources Institute, Environmental Benefits of Wood Products, Oregon Forest Resources Institute, 317 SW Sixth Ave., Suite 400, Portland, Oregon. U.S.A., 2011. pp.2-7.

[3] A. L. Antwi, What We Have; Our Forest Heritage, in Workshop for Media Personnel on Forestry and Wildlife Reporting Proceedings, Department of Silviculture and Forest Management-FRNR-KNUST, Kumasi. Ghana, 1999. pp.24-29.

[4] J. A. Walton, Woodwork in Theory and Practice, $5^{\text {th }}$ Edition, The Australian Publishing Co. Pty Ltd., Sydney. Australia, 1974. $472 \mathrm{pp}$.

[5] Ministry of Lands and Natural Resources, Draft -GhanaForest Investment Program (FIP) Plan, March 2012. pp. 566.

[6] J. G. Haygreen, and J. L. Bowyer, Forest Products and Wood Science-An Introduction, $3^{\text {rd }}$ Edition, IOWA State University Press, Ames.U.S.A., 1996. 485pp. 
[7] FAO, 2009, In; M. Amoah, Appiah-Yeboahand, J., and Okai, R., Characterization of physical and mechnainical properties of Branch, Stem and Root Wood of Iroko and Emire tropical trees, Research J. of Applied Science, Engineering and Technology, Vol. 4 No. 12, 2012. pp. 1754-1760.

[8] J. Ayarkwa, Y. Hirashima, and Y. Sasaki, Effects of Finger Geometry and end Pressure on the Flexural Properties of Finger-Jointed Tropical African Hardwoods, Forest Products Journal, Vol.50 No. 11/12, 2000. pp. 53-63.

[9] M. Cionca, L. Badescu, O. Zeleniuc, and A. Olarescu, Ecodesign approach. A research regarding the potential use of branches in new wooden products. Poster presentation, In Proc. International Conference on Environmentally Compatible Forest Products. ECOWOOD, 20-22 Sept. Fernando Pessoa University, Porto, Portugal, 2006. pp. 107110 .

[10] H. M. El-Lakany, 2004. In; R. A. Sedjo, Towards commercialization of genetically engineered forests: Economic and social considerations, Resources for the future, Washington D.C., $2006 . \quad 45 \mathrm{pp}$. http//www.rff.org/rff/Documents/RFF-RptcommercializationGEForest.pdf. (Accessed $6^{\text {th }}$ May, 2013.

[11] M. Hilton, 2001. In; L. Gurau, M. Cionca, H. MansfieldWilliams, G. Sawyer, and O. Zeleniuc, Comparison of the Mechanical Properties of Branch and Stem Wood for Three Species; in Wood and Fibre Science, Vol. 40 No.4, Society of Wood Science and Technology. U.K., 2008. pp. 647-656.

[12] M. Amoah, 2008. In; M. Amoah, J. Appiah-Yeboahand, and R. Okai, Characterization of physical and mechnainical properties of Branch, Stem and Root Wood of Iroko and Emire tropical trees, Research Journal of Applied Science, Engineering and Technology, Vol. 4 No.12, 2012. pp. 17541760 .

[13] R. Okai, A study on the milling and strength properties of branchwood, Fellowship Report. In; ITTO Tropical Forest Update Vol.12 No. 1, 2002. pp.24-25. www.itto.int/direct/topics/topics_pdf_download/topics_id=1 $630000 \&$ no $=1$. (Accessed, $15^{\text {th }} \overrightarrow{\text { March, }}, 2012$ ).

[14] M. Amoah, and G. Becker, Assessment of logging efficiency and development of Allometric Models for predicting stumpage volume of some commercial tree species in Ghana. International Forest Review, Vol. 11 No.1, 2009. pp.1-11.

[15] R. Okai, K. Frimpong-Mensah, and D. Yeboah, Characterization of strength properties of branchwod and stem wood of some tropical hardwood species, Wood Science and Technology Vol. 38, 2004. pp. 163-171.

[16] M. Amoah, J. Appiah-Yeboahand, and R. Okai, Characterization of physical and mechnainical properties of Branch, Stem and Root Wood of Iroko and Emire tropical trees, Research Journal of Applied.Science, Engineering and Technology, Vol. 4 No.12, 2012. pp. 1754-1760.
[17] Society of American Foresters, Dictionary of Forestry in Wikipedia, the free encyclopedia, 1998. http//en.wikipedia.org/wiki/logging, (Accessed $5^{\text {th }}$ May, 2013).

[18] N.H. Pillsbury, and D.R. Pryor, Volume equations for young growth Softwood and Hardwood species at BOGGS Mountain Demonstration State Forest. Natural Resource Management Department, California Polytechnic State University. San Luis Obispo, 1989. 31pp.

[19] C. Dean, Calculation of wood volume and stem taper using Terrestrial Single-Image Close-Range Photogrammetory and contemporary software tools, Silva Fennica Vol. 37 No. 3, 2003. pp. 359-380.

[20] L. Gurau, M. Cionca, H. Mansfield-Williams, G. Sawyer, and O. Zeleniuc, Comparison of the Mechanical Properties of Branch and Stem Wood for Three Species; In Wood and Fibre Science Vol. 40 No. 4, Society of Wood Science and Technology, U.K., 2008. pp. 647-656.

[21] Ministry of Forests, Lands and NRO, Scaling Manual, 2011. http;//www.for.gov.bc.ca/ftp/hva/chapter 4. (Accessed $8^{\text {th }}$ November, 2012).

[22] G. Pleydell, Tropical Timbers of Ghana, Timber Exports Development Board, Takoradi. Ghana, 1994. 86 pp.

[23] J. A. Corrals-Rivas, M. Barrio-Anta, O. A. Aguirre-Calderon, and U. Diéguez, 2007, In: M. Amoah, and G. Becker, Assessment of logging efficiency and development of Allometric Models for predicting stumpage volume of some commercial tree species in Ghana. International Forest Review, Vol. 11, No.1, 2009. pp. 1-11.

[24] P.R. Larson, 1963., In: M. Amoah, and G. Becker, Assessment of logging efficiency and development of Allometric Models for predicting stumpage volume of some commercial tree species in Ghana. International Forest Review, Vol. 11, No.1, 2009, pp. 1-11.

[25] A. R. Adam, A. Ofosu-Asiedu, C. Dei-Amoah, and A. Asante-Asiamah, 1993, In; Amoah, M., and Becker G., Assessment of logging efficiency and development of allometric models for predicting stumpage volume of some commercial tree species in Ghana. International Forest Review, Vol. 11 No. 1, 2009. pp. 1-11.

[26] Dadzie, P.K., Preliminary guide for entrepreneurship studies in the wood products industry-A necessary step towards enhancing value addition to wood resources for wealth creation and development. A conference paper for the $1^{\text {st }}$ International Conference for Entrepreneurs and Entreprneurship Educators, Researchers and Entreprenueurs in Africa (CEEREA, 2011), Kumasi. Ghana. $28^{\text {th }}-30^{\text {th }}$ November, 2011.

[27] LI 1649, Timber resource management regulations, Part VIRegistration and use of chainsaws, Forestry Commission, promulgated on $9^{\text {th }}$ November, 1998. pp. 1-20. 